Anna Ostrowska

\title{
THE LAW OF STATE AND LOCAL GOVERNMENT GRANTS - NECESSARY AMENDMENTS AND REFORMS
}

\section{Introduction}

There has been considerable stabilization and standardization in public revenues law, especially in tax law which, apart from some amendments, does not need radical legislative reforms. By contrast, public expenditures law (public spending law), especially the regulations on government grants, needs not only amendments, but also a general legislative reform to make it more transparent and effective. One may venture to say that the public expenditures will contribute to political and legislative changes in the $21^{\text {st }}$ century just like the evolution of taxes resulted in the birth of parliamentary democracy in previous centuries.

The first projects of performance-based budgeting which are undertaken nowadays in Poland are good examples of enhancing the role of public spending law. Performance-based budgeting, which has long been in effect abroad ${ }^{1}$, is an instrument of developing a budget itself and of informing on the resource allocation decisions. In Poland, however, the law on making grants and its defectiveness has not been focused by public finance doctrine and by the legislator yet.

\section{Imperfection of granting law}

The 1997 Constitution of the Republic of Poland reflects modern European trends and provides a framework for public and local government finance by setting forth its basic rules and principles. However, the Constitution does not provide for any regulations or principles for public spending (public expenditures), giving freedom to the legislator to regulate this sphere in statutes. The main regulations on

J. Mercer, What is a Performance Budget? Overview, http://www.governmentperformance.info, June 26th, 2008. 
public expenditures were set in the 2005 Public Finance $\mathrm{Act}^{2}$, but unfortunately most of them have rather statistical and schematic character and are inefficient in solving many budgetary problems and answering many questions.

The 2005 Public Finance Act provides a wide range of regulations on state government grants, however, many of them are not complete or adequate to what the Parliament sets in the State Budget Act decreed each year. State government grants for private investment are a good example of this relation, because the real character and variety of these grants are only provided by the State Budget Act (Schedule: Long-Term State Programs) and the analysis of the functioning of Polish Special Economic Zones.

Local and regional governments have a great many problems with the application of the law on making grants as the 2005 Public Finance Act does not define or categorize local government grants at all and provides very few regulations on them. The European, universal right of local government to make grants for designated tasks or units (which derives from the financial independence of local government) in many cases can hardly be applied in Poland. One of the main principles of local governments finance in Poland is that local governments can act only when they are allowed or obliged to do so by law. The law on making grants by local government is spread in many different acts and the permission to make a grant is usually formulated as the blanket clause, which in practice results in giving up granting by local government.

Grants and subventions constitute about $50 \%$ of total expenditures of the state budget and most of them $(80 \%)$ are mandatory spending on the public tasks conducted by local governments and state special purpose funds. It is worth remarking here that the ratio mentioned above proves how much public revenues are centralized in the Polish state budget.

At local level, expenditures for making grants constitute about $15 \%$ of total expenditures of local governments budgets and most of them are mandatory spending (mandatory grants) on the public local tasks, like theatres, museums, private and public kindergartens, private primary and secondary schools, private welfare houses and non-profit organizations. There are many statutes which allow local governments to make a grant (as discretionary spending) for other units, but unfortunately the permission is stipulated in an unclear way like: "financial support" or "financial help". Such regulations remain "dead" if we take into the consideration the local government principle of acting only by a legal permit mentioned above. If the statute does not explicitly indicate that this "financial support or help" can be 
performed by making grant from a local budget, a local government would rather give up any support or help, not to be suspected of illegal action by a supervision body.

The structure and character of state government grants are much more different than the structure and character of local government grants, which results from the different nature (different public tasks) of both the governments and their budgets. Therefore, it seems obvious that the substantive law (material law) of making grants may remain different at the central and local levels of the government (e.g, the definition of a grant, categories of grants, tasks and units for which grants can be designated). However, the formal granting law (its main principles), should remain the same at the central and local levels for the safety of public finances and should stipulate general legal rules on: grant procedures, control of grantees, grants refunds and penalties or grant frauds.

\section{State government grants}

Decentralization of public tasks to newly created levels of local government (counties and regions), which took effect in 1999, caused a great change in the structure of state budget expenditures. Since then, grants and subventions for local governments and state special purpose funds have amounted to about $50 \%$ of total state budget expenditures each year. It is worth pointing out here that there is a confusion with reference to the terms of this kind of budgetary transfer in Polish law (fortunately only at the central level). There are common grants and two kinds of subventions: 1) a general subvention for local governments - which includes 'education' and 2) a subvention for political parties in the structure of state budget grants. It is quite confusing to use both terms: grants and subventions, especially when we compare the etymological meaning of "subvention" (aid or help) with the real functions of subventions mentioned above and when we consider that other European countries use terms like General Grant (Block Grant) instead of "subvention".

According to Article 106 (1) of Public Finance Act 2005, State Budget Reports present eight economic groups of expenditures every year and 'Grants and Subventions' group constitutes one of these groups. The analysis of this group shows a great variety of state government grants, which we cannot find in the catalogue presented in Article 106 (2) of Public Finance Act 2005. 
Table 1. State Government Grants and Subventions in 2007 (selected positions)

\begin{tabular}{|c|c|c|c|}
\hline & & Amount & \multirow[b]{2}{*}{$\%$} \\
\hline & & in thousand $\mathrm{zl}$ & \\
\hline \multirow{2}{*}{1.} & $\begin{array}{l}\text { General Subvention for Local Gov. } \\
\text { including: }\end{array}$ & 36.756 .209 & 32,6 \\
\hline & $\begin{array}{l}\text { - education } \\
\text { - other parts }\end{array}$ & $\begin{array}{l}28.204 .949 \\
8.551 .260\end{array}$ & \\
\hline 2. & Grants for state special purpose funds & 39.034 .834 & 34,5 \\
\hline 3. & Grants for local governments & 16.841 .267 & 14,9 \\
\hline 4. & $\begin{array}{l}\text { Grants for mandatory tasks } \\
\text { conducted by the other units of } \\
\text { public finance sector }\end{array}$ & 1.580 .144 & 1,3 \\
\hline \multirow[t]{2}{*}{5.} & $\begin{array}{l}\text { Grants defined as to the objective, } \\
\text { including: }\end{array}$ & 547.226 & 0,3 \\
\hline & $\begin{array}{l}\text {-grants for units of PFS* } \\
\text {-grants for units which do not belong to PFS }\end{array}$ & $\begin{array}{l}40.067 \\
507.159\end{array}$ & \\
\hline \multirow[t]{2}{*}{6.} & $\begin{array}{l}\text { Grants defined as to grantee, } \\
\text { including: }\end{array}$ & 17.194 .235 & 15,3 \\
\hline & $\begin{array}{l}\text { - grants for units of PFS } \\
\text {-grants for units which do not belong to PFS }\end{array}$ & $\begin{array}{l}16.258 .884 \\
935.351\end{array}$ & \\
\hline 7. & $\begin{array}{l}\text { Grants for non-governmental } \\
\text { organizations }\end{array}$ & 1.055 .887 & 1,0 \\
\hline 8. & Subventions for political parties & 94.834 & 0,1 \\
\hline TOTAL & & 113.104 .636 & 100,00 \\
\hline
\end{tabular}

* public finance sector

Source: own calculations on the basis of: State Budget Report 2007, Part I, Chapter 3.4. Expenditures according to the main economic groups, Ministry of Finance, Warsaw 2007, www.mf.gov. pl, June $16^{\text {th }}, 2008$.

A few conclusions with regard to the specific nature of public finance in Poland can be drawn from the analysis of the above data. First of all, the number of subventions and grants for local governments is nearly the same as the number of grants for state special purpose funds, which is the evidence of diversification and centralization of public finance. Secondly, there is a considerable number of grants defined as to grantee, which, according to public finance theory, should be applied 
in exceptional cases only. Thirdly, we cannot find any grants for public and private investments in the above group because they are calculated into the total number of capital expenditures of state budget.

It is sufficient to remark here that Public Finance Act 2005 sets many regulations on grants for public and private investments. Under the regulations the legislator is obliged to present the grants in the schedule of State Budget Act. In fact, we have to look for this kind of grants in the total number of state budget capital expenditures and we can also find them in the Schedules of State Budget Act (which refers to other questions) like: Schedule 13. Long-Term State Programs (which presents grants for private investments conducted in Polish Special Economic Zones) ${ }^{3}$ and Schedule 6. Long-Term Public Investment's Programs (which presents grants for public investments conducted by public units).

\section{Local government grants}

In comparison with the state government granting law, there are a very few regulations on local government granting in Public Finance Act 2005, which results in many problems with the application of the law on grants at local level. A great number of administrative and courts' judicial decisions are examples of such difficulties. Supervision bodies or administrative courts usually prohibit local governments from making a grant, if there are no clear legal grounds for grants from local budget. We can sum up here, that local governments' "freedom of granting" is strictly limited by the material statutes which provide different types of granting procedures. At the same time, however, many of these statutes include only a blanket regulation on that matter, which, we can say, is a kind of encouragement for local governments to make spending on a particular sphere. But what kind of budgetary transfer can they use in such a situation? Should they set a local programme on these grants? Proper amendments to this kind of statutes, which would provide a clear indication of budgetary transfer, are expected from the legislator.

The phenomenon described above is best reflected in the area of local government grants for the units which do not belong to $\mathrm{PFS}^{4}$ (non-governmental organizations, private educational units, professional sports clubs), especially when they act as joint stock company or limited liability company. However, legal permission to make grants with regard to the units belonging to PFS results in problems too, which could

\footnotetext{
3 Polar S.A., Philips Polska Sp. z o.o., Volvo Polska Sp z o.o., Toyota Polska Sp z o.o., Shell Polska Sp. z o.o. IBM Polska Sp. z o.o. and others are in the group of corporations which make investments in Polish Special Economic Zones and receive state government grants. 
be reflected in the questions: 'What kind of grant can be made?', 'Can one local government make a grant for the unit of another local government (for example regional government for a county hospital)?', 'Can a local government make a grant for investments of their culture units (which are separate and independent legal persons)?' and finally, 'Can a local government make a grant at all (if the statute provides only blanket terms like "financial aid or help")?’6

Polish regional governments have great financial and legal capabilities for making grants, which results from the nature of their public tasks, in particular in redistributing EU sources. Grants constituted about 35\% of total regional governments expenditures in previous years and will make about 50\% in 2008 .

Table 2. Regional Government Grants in 2008 (example of Podlaskie Vivodeship)

\begin{tabular}{|c|c|c|c|}
\hline & & $\begin{array}{c}\text { amount } \\
\text { /in zl/ }\end{array}$ & $\%$ \\
\hline \multirow{2}{*}{1.} & $\begin{array}{l}\text { Grants defined as to objective, } \\
\text { including: }\end{array}$ & 30.614 .105 & 16,46 \\
\hline & $\begin{array}{l}\text { - grants for regional train transportation } \\
\text { - grants for regional bus transportation }\end{array}$ & $\begin{array}{l}12.914 .105 \\
17.700 .000\end{array}$ & \\
\hline \multirow[b]{2}{*}{2.} & Grants defined as to grantee, including: & 22.307 .050 & 11,99 \\
\hline & $\begin{array}{l}\text { - grants for regional hospitals } \\
\text { - grants for theatres } \\
\text { - grants for regional philharmonic hall } \\
\text { - grants for regional libraries } \\
\text { - grants for regional museums } \\
\text { - grants for cultural centers } \\
\text { - grants for medical university }\end{array}$ & $\begin{array}{l}840.000 \\
3.532 .850 \\
4.292 .000 \\
3.870 .000 \\
7.130 .000 \\
2.642 .200 \\
704.220\end{array}$ & \\
\hline \multirow[b]{2}{*}{3.} & $\begin{array}{l}\text { Grants for designated tasks } \\
\text { including: }\end{array}$ & 21.362 .660 & 11,49 \\
\hline & $\begin{array}{l}\text { - grants for units which do not belong to PFS* } \\
\text { (non-profit organizations) } \\
\text { - grants for units of PFS }\end{array}$ & $\begin{array}{l}3.640 .000 \\
3.496 .000\end{array}$ & \\
\hline
\end{tabular}

5 There are four main categories of government grants in Polish law: grants for designated tasks, grants defined as to grantee, grants defined as to objective and grants for investments.

6 The blanket terms, mentioned above, can be found in e.g.: ustawa z dnia 29 lipca 2005 r. o sporcie kwalifikowanym /on professional sport/ (Dz.U. No 155, item 1298 as amended), ustawa z dnia 27 lipca 2005 r. Prawo o szkolnictwie wyższym /Higher Education Act/ (Dz.U. No 164, item 1365 as amended). 
The Law of State and Local Government Grants - Necessary Amendments and Reforms

\begin{tabular}{|c|c|c|c|}
\hline \multirow[b]{2}{*}{4.} & $\begin{array}{l}\text { Grants for investments } \\
\text { including: }\end{array}$ & 11.529 .000 & 6,22 \\
\hline & $\begin{array}{l}\text { - grants for regional hospitals } \\
\text { - grants for regional theatre } \\
\text { - grants for regional library }\end{array}$ & $\begin{array}{l}10.710 .000 \\
560.000 \\
189.000\end{array}$ & \\
\hline \multirow{3}{*}{5.} & $\begin{array}{l}\text { Grants redistributed from EU funds } \\
\text { including: }\end{array}$ & 100.102 .837 & 53,84 \\
\hline & $\begin{array}{l}\text { - from } 2007-2013 \text { EU perspective } \\
\text { - from previous EU perspective }\end{array}$ & $\begin{array}{l}97.405 .177 \\
2.697 .660\end{array}$ & \\
\hline & TOTAL & 185.915 .652 & 100 \\
\hline
\end{tabular}

* Public Finance Sector

Source: own calculations on the basis of: Podlaskie Voivodeship Budget 2008, Biatystok 2008, www.wrotapodlasia.pl, June 16th, 2008.

We may conclude from the table presented above that there is a considerable variety of regional government grants. However, this variety derives mainly from the specific character of Polish public finance sector and from the mechanism of financing particular units belonging to that sector. For example, regional governments grants for theatres, museums, philharmonic hall, libraries are, in fact, the instruments of financing whole activity of these institutions and kind of mandatory local and regional spending for culture. These grants, therefore, can be treated as General Culture Grant and should have general, universal grants' procedures and principles, based on regional culture programme. Grants for culture units do not have the proper "granting" function (aiding function) in Poland, which derives from the fact that, although these institutions are independent legal persons, nevertheless, they are not able to finance their whole activity from their own incomes. However, some of them, especially situated in Western Poland, are trying to do so.

Moreover, local and regional government grants for hospitals have another specific character and constitute a discretionary instrument of financial help provided to hospitals. The dramatic financial situation of many hospitals in Poland forces local and regional governments to provide them with a grant, although the governments are not obliged to do so.

On the whole, an appropriate procedure of making grants for non-governmental organizations can be observed, provided by April 24 2003 Act on Public Benefit and Volunteer Work ${ }^{7}$. This probably derives from long, good experience and development of European third sector (NGO sector) and from legal activity of European Economic

7 Ustawa z dnia 24 kwietnia 2003 r. o działalności pożytku publicznego i o wolontariacie (Dz. U. No 96, item 873 as amended) 
and Social Committee. However, one question remains unanswered in this sphere in Poland: Could a joint stock company or limited liability company receive a status of a non-governmental organization and a non-profit organization and be granted by local governments?

\section{Concluding remarks}

This article has focused on only some factors with regard to the shape of law on state and local governments grants in Poland. The legal framework of these grants provided by Public Finance Act 2005 is not appropriate for a modern state. The law on government grants requires a truly radical redefinition and changes, which would adopt all principles of modern granting, such as transparency, cooperation, programming and clear procedures. In particular, these changes are desirable at local level, as great disorganization, diversity of systems and "water" regulations could be observed there. To put it plainly, the law on making government grants requires not only amendments, but a general reform, which could be conducted by means of a separate chapter in Public Finance Act 2005 or a separate act on making government grants. 


\section{Streszczenie}

Istotną częścią nauki prawa finansowego staje się obecnie prawo wydatków publicznych, w tym prawo dotacyjne. Niejasne i niejednoznaczne przepisy dotacyjne samorządu terytorialnego w ustawach materialnych oraz „skromna” regulacja tego zagadnienia $\mathrm{w}$ ustawie z $2005 \mathrm{r}$. o finansach publicznych, przy uwzględnieniu zasady działania samorządu terytorialnego na podstawie i w granicach prawa, wywołują liczne problemy interpretacyjne w zakresie jego kompetencji dotacyjnych. Artykuł przedstawia analizę dotacji udzielanych z budżetu państwa i budżetów jednostek samorządu terytorialnego oraz wskazuje na potrzebę przeprowadzenia stosownych nowelizacji prawa w tym zakresie. 